obituary

\section{Sir Landsborough Thomson}

Arthur Landsborough Thomson died on 9 June 1977 at the age of 86 . With his death we have lost the last of that small group of men who, in the early years of this century, brought into being the organisation in this country for the national suppont of scientific research. A noted biologist, with a natural talent for administration, he combined in his own person the qualities required for translating scientific policy into administrative practice. It was, therefore, fortunate that circumstances brought him, at an early stage in his career, into the position of chief of staff at the headquarters of the then embryonic Medical Research Council.

Born in Edinburgh in 1890, Thomson spent his formative years in Aberdeen where his father was Regius Professor of Natural History. After graduating as MA in 1911, he elected for an academic career in zoology. In preparation for this, it was decided, in line with the spacious traditions of those days, that he should first broaden his education. So he went to study, first at Heidelberg, and then in Vienna from where he only just succeeded in escaping before the outbreak of the First World War.

Arrived back in Scotland, he immediately joined the Argyle and Sutherland Highlanders. With that distinguished regiment he went to France and saw hard service. It was then that his flair for administration first revealed itself. As a result he was recruited to the staff and ended the war, in the rank of Lieutenant-Colonel, as an Assistant Quartermaster-General at General Headquarters. He thus came to take a diffierent view of his future. Returned to civilian life, he went to the Treasury. But he was only there for a short while. Sir Walter Fletcher, the then Secretary of the Medical Research Council, was looking for a man to build up the administrative side of his organisation; and Thomson was the obvious choice for the post.

When Thomson joined the MRC the entire staff at headquarters, apart from the Secretary, numbered no more than half-a-dozen persons. When he left, some forty years later, the figure was 130. Nevertheless, even then, the staff was remarkably small when set against the size of the Council's organisation and the scope of its activities. In part this was due to its having grown

\section{Sorry, for copyright reasons some images on this page may not be available online}

naturally rather than as a result of reforms imposed from outside. More especially, however, it was due to Thomson's wide range of capabilities. With his scientific background, and his continued personal involvement in research in ornithology, he was never in danger of mistaking means for ends and complicating administrative procedures accordingly. For him the first task was to identify the scientific requirements of any given problem and then devise measures for meeting these. Not that he ever fell into the opposite error of ignoring those basic principles and methods that are applicable to all administration, whatever its purpose. But he required that every case be approached on its merits, never on the basis of precedent. That was the atmosphere that permeated the whole office under his sway. As a result, agreements were reached with the minimum of fuss and, although prospective applicants might go away disappointed, they could seldom, if ever, feel they had been misunderstood.

But Thomson was far more than the head of the Council's machinery for supporting its purely research interests. Having a realistic appreciation of the social and political context in which the Council operated, and a shrewd eye for impending developments, he brought his own expertise to bear on the formation of policies for translating scientific knowledge into practice. An example is the part he played in creating the Public Health Laboratory Service. Originally conceived, in the mid 1930 s, as a defence against bacterial warfare, this quietly came into being on the outbreak of the Second World War. Such things do not happen by accident. They are the fruit of realistic vision and informed understanding by those responsible for planning the logistics of such an operation. In the event, the threat this particular service was devised to counter never materialised, but the network of laboratories it provided proved so useful in extending our control over the ordinary infections of civilian life that it was put on a permanent footing and eventually transferred, as a going concern, from the Council to the National Health Service. That Thomson should have been accepted without question as chairman of the expert board which directed such a service, is a sufficient indication of how he was regarded by the scientific community. When I want the MRC, I was exceptionally fortunate in having him as a colleague and mentor, for to work with him was a professional education in itself.

Yet all the time he had another life: that of a distinguished ornithologist. From his earliest years, he had taken an informed interest in wild life. Later, this developed into his classical studies on bird migration. But, at heart, he was always a field naturalist and, in this context, his knowledge was encyclopaedic. Consequently, he was, at one time or other, chairman of all the major organisations for ornithology in Great Britain and, in 1954, President of the XIth International Congress held in Basle. After his retirement from the MRC, his interests in this field could develop freely. He travelled widely, especially in the tropics. He took a major part in the enquiry into the Serengeti Park. From 1954 to 1960 , he was President of the Zoological Society of London, from 1964 to 1969 , Chairman of the Council for Nature, and from 1967 to 1969 , Chairman of the Trustees of the British Museum (Natural History). And, with the help of his devoted wife, he edited his great New Dictionary of Birds.

In spite of these commitments, when he came to retire, Thomson readily accepted an invitation from the Medical Research Council to write an account of its development. Having been personally involved in this for most of the period which it covered, he was in a unique position to undertake this task. The outcome, Half a Century of Medical Research, is far more than an 
institutional history. In it he sets out, with characteristic objectivity, the various developments in the British organisation of medical research and the administrative lessons to be learned from these. As such its relevance extends beyond the sphere of its immediate subject to a central problem of the scientific and technological age in which we are now living; namely, that of providing, not only for the development of scientific knowledge, but also for its integration into the machinery of government.

Like his old schoolfellow, Wilson Jameson, the architect of the National Health Service, Thomson understood that for any human institution to be a success, it must satisfy both of two fundamental requirements. It must be in conformity with the realities of that it seeks to organise. It must equally be in conformity with the deeply held sentiments of those who have to make it work. In his own time, Landsborough Thomson contributed his quota to realising these conditions and, thereby, to creating the institutions required if activities that depend on acts of individual judgment are to be integrated into the structure of social organisation. That was the deeper significance of his life's work and his essential legacy to future generations.

Harold Himsworth

\section{Meirion Thomas}

MEIRION Thomas who died in his eighty-third year on 5 April 1977 at Tywyn in his native Wales will be remembered not only for his academic and athletic prowess but also for sterling personal attributes.

Born in North Wales in 1894, his early academic career as a student of University College of North Wales was interrupted when he was commissioned in the South Wales Borderers in 1914 and later transferred to the Special Companies Division of the Royal Engineers. On demobilisation in 1919 he went to Cambridge (Trinity Hall) where, inspired by his contacts with Gowland Hopkins, F. F. Blackman and Muriel Onslow, among others, he developed interests in plant physiology and biochemistry. He joined the Botany Department in the Newcastle division of Durham University as a lecturer in 1924, became Reader in Plant Physiology in 1942, and in 1946 Professor and Head of the Department where he remained until retirement in 1961.

His book Plant Physiology, first published in 1935, brought him to the fore because of its new approach to the subject with its emphasis on the experimental study of plant metabolism. It was reprinted and revised periodically to a fifth edition in 1973 , always re- taining his aim of educating students in the development of ideas and investigation rather than simply presenting the present state of knowledge. His main research interests as covered by his own publications embraced various aspects of respiratory and acid metabolism with occasional ventures into other fields e.g. melanism, but the sum total of his contributions to science and life could only be assessed by perusal of the long list of students, colleagues and friends who would readily attest that whatever they have achieved, and some have achieved great distinction, they owe much to their contacts at some stage with him.

Meirion Thomas's eminence in science was marked by his election to the Royal Society in 1949. Two other distinctions which gave him great pleasure, and of which he was justifiably proud, were the award of the Charles Reed Barnes Honorary LifeMembership of the American Society of Plant Physiologists in 1963, and the Honorary Degree of D.Sc. of the University of Wales in 1964.

At Cambridge he won a soccer blue and played cricket, being elected to the Crusaders Club in 1923. He continued enthusiastic participation in both with Northern clubs for many years and remained actively interested in them throughout his life. A few years after retirement, his love of Wales, its language, and its cultures drew him to Tywyn, but not as a recluse. He maintained contacts with all his friends, continued to attend scientific meetings and enjoy a full life. He will be remembered with respect and great affection by all who knew him.

$$
\text { S. L. Ranson }
$$

\section{A. V. Nikolaev}

ACAdemician Anatolii Vasil'evich Nikolaev, a leading Soviet expert in geochemistry and the utilisation of natural resources died on February 13, 1977.

Nikolaev was born in 1902. He graduated from the University of Leningrad in 1924, and soon afterwards became involved in the problems of resource utilisation. From 1927 to 1931 he was head of the Pavlodar Salt Expedition of the Commission to Study Production Resources of the Academy of Sciences of the USSR, and from 1931 to 1935 he headed a similar, combined, expedition to the Kulunda area. Between 1934 and 1957 he worked at the Institute of General and Inorganic Chemistry of the Academy of Sciences in the USSR, and, simultaneously, held various teaching posts in Moscow, at the Polygraphic Institute and the Institute of Non-Ferrous Metals and Gold, becoming a Professor at the latter Institute in 1946. In 1957 he moved to Novosibirsk, to become Director of the Institute of Inorganic Chemistry of the Siberian Branch of the Academy of Sciences of the USSR. The following year he was elected a Corresponding-Member of the Academy of Sciences and a Praesidium Member of the Siberian Branch. He became a full member of the Academy in 1966.

Nikolaev's main works deal with the physical and chemical analysis of salt systems, thermography and radiochemistry. His interests were wide and his published titles reflect this diversity, ranging from The Kulunda Salt Lakes and means of desalinating them and The physico-chemical study of natural resources, to Protection against radioactivity, and $A$ study of the processes of oxidation of complex compounds of divalent platinum.

In 1947, he won the Vernadskii prize, and, in 1967, on the occasion of his 65 th birthday, he was awarded the Order of Lenin.

Vera Rich

\section{W. F. McClare}

Colin W. F. McClare, lecturer in biophysics at King's College London, died on 4 January 1977 at the age of 39 .

$\mathrm{He}$ won an open Exhibition to Emmanuel College Cambridge from Felsted School in 1955 and read Natural Sciences, specialising in chemistry. His interest in applying chemical concepts to biological problems was already apparent in his $\mathrm{PhD}$ project on free radicals in biology and was developed further when as a Beit Fellow he studied energy transfer in nucleic acids.

After his appointment at King's College in 1963, he turned his attention to fundamental problems in bioenergetics, especially muscle contraction. $\mathrm{He}$ stressed the importance of time scales in thermodynamics and proposed a muscle model employing stimulated resonant energy transfer. He strongly advocated that the secret of ATP lies in the molecular details of its hydrolysis and not simply in its overall free energy change.

Colin was a person of great enthusiasm and intensity of thought. His interests ranged from practical methods of analytical biochemistry to the social and philosophical implications of science. His search for excellence and his competitive spirit showed in his love of discussion and in his sporting activities. As a teacher, he inspired his students through an outstanding ability to make ideas come to life.

$\mathrm{He}$ is survived by his wife Gill. His stimulating and ever-helpful presence will be missed by his many friends.

W. R. Lieb

I. Gonda 